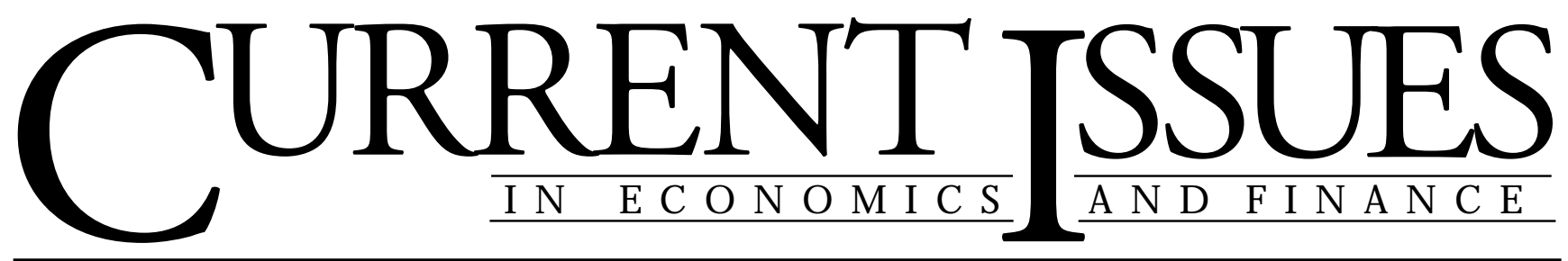

September 1998

Volume 4 Number 9

\title{
Bank Holding Company Capital Ratios and Shareholder Payouts
}

\author{
Beverly Hirtle
}

Last year's sharp drop in the capital ratios of bank holding companies could cast doubt on the companies' future capital strength, especially if credit quality eroded significantly or if profitability weakened. However, an analysis linking the drop in ratios to bank efforts to increase shareholder payouts in a period of strong profitability suggests that these concerns are premature.

Bank holding companies have significantly increased their capital ratios since the late 1980s and early 1990s, when losses from real estate and other troubled lending sectors precipitated a wave of bank failures. Nearly all banking institutions now have capital ratios that comfortably exceed regulatory minimums. In large part, these ratios reflect a string of highly profitable years in which banks retained a significant portion of their earnings while increasing payouts to shareholders.

During 1997, however, average capital ratios at U.S. banking institutions declined, particularly among the largest bank holding companies. These declines raise the question, Could banking institutions face future capital constraints, particularly if their credit quality were to deteriorate significantly or if profitability were otherwise to weaken? In the extreme, such constraints could undermine banks' ability to expand their lending activities or to participate fully in other key financial services.

In this edition of Current Issues, we assess the seriousness of these concerns by examining the reasons for the decrease in bank holding company capital ratios in 1997. We find that the decrease is attributable to banking institutions' efforts to increase payouts to shareholders in an environment of strong profitability. These payouts-in the form of dividend payments and net stock repurchases-grew dramatically in 1997, both in dollar terms and as a share of net income. In fact, among the twentyfive largest U.S. bank holding companies_all of which had assets of $\$ 45$ billion or more-shareholder payouts exceeded net income on average for the group.

Such high shareholder payouts might be seen as a threat to banking institutions' capital strength if profitability faltered. However, we find that the sharp rise in shareholder payouts during 1997 appears to have been driven primarily by increases in net stock repurchases rather than by a run-up in dividend payments. The composition of these payouts is important because banking companies can cut back on repurchases more easily than they can reduce dividend payments if earnings begin to drop. For this reason, the recent increase in overall shareholder payouts by bank holding companies may not be cause for immediate concern.

\section{Capital Ratios}

\section{Calculating Capital Ratios}

U.S. banks and bank holding companies are subject to three regulatory capital ratios that together are intended to gauge their capital strength. Each ratio has a measure of regulatory capital in the numerator and a measure of the extent of the institution's activities in the denominator. Two different measures of regulatory capital are used in calculating the ratios: tier 1 capital, which consists primarily 
of "core capital" elements such as common stock and certain forms of preferred stock, and total capital, which consists of tier 1 capital plus "supplementary" (tier 2) capital elements such as subordinated debt. ${ }^{1}$

The first two ratios are the tier 1 and total capital ratios, which are calculated as the ratios of tier 1 and total capital to an institution's risk-weighted assets. By incorporating risk-weighted assets, these ratios are designed to measure a bank's capital relative to its risk exposure. As a result, the ratios are frequently referred to as a bank's "risk-based capital ratios." In contrast, the third capital ratio - the leverage ratio - is intended to provide a measure of a bank's capital resources relative to a measure of the scale of its overall activities without any adjustment for risk. This ratio is calculated as tier 1 capital divided by average total assets. To meet minimum capital requirements, bank holding companies must maintain tier 1 capital ratios exceeding 4 percent, total capital ratios above 8 percent, and leverage ratios in excess of 3 percent. $^{2}$

\section{Capital Ratios}

At the close of 1997, average capital ratios for all U.S. bank holding companies were well above the minimum regulatory capital requirements. The average tier 1 capital, total capital, and leverage ratios were 9.0 percent, 12.5 percent, and 7.1 percent, respectively. Despite ending the year at comparatively high levels, however, the average capital ratios had fallen markedly during 1997. These falls continued a slight downward trend that began in the mid-1990s, although the decreases in the ratios were noticeably larger in 1997 than in earlier years. By year-end, the average tier 1 and total capital ratios for all U.S. bank holding companies had declined about 50 basis points from their end-of-1996 levels. These drops were even more pronounced among the twenty-five largest U.S. bank holding companies, whose average tier 1 and total capital ratios had decreased by 62 and 69 basis points, respectively (Chart 1). ${ }^{3}$ For both sets of institutions, the decline in the average leverage ratio was less pronounced; it essentially reversed an upturn in 1996 and returned these ratios to the levels that had prevailed in the mid-1990s.

For many observers, any such slides in the risk-based capital ratios could be a troubling development, a sign that U.S. banking companies are likely to face capital constraints if profitability deteriorates. Conventional wisdom holds that banks should build up capital ratios during periods of high profitability to have a strong capital base that can withstand inevitable future downturns. Indeed, U.S. banking companies have made a serious effort in the past several years to build up capital ratios following the period of industry turmoil in the late 1980s and early 1990s. But the view that the 1997 drop in capital ratios represents a potentially alarming weakening of banks'

\section{Chart 1 \\ Annual Change in Large Bank Holding Companies'}
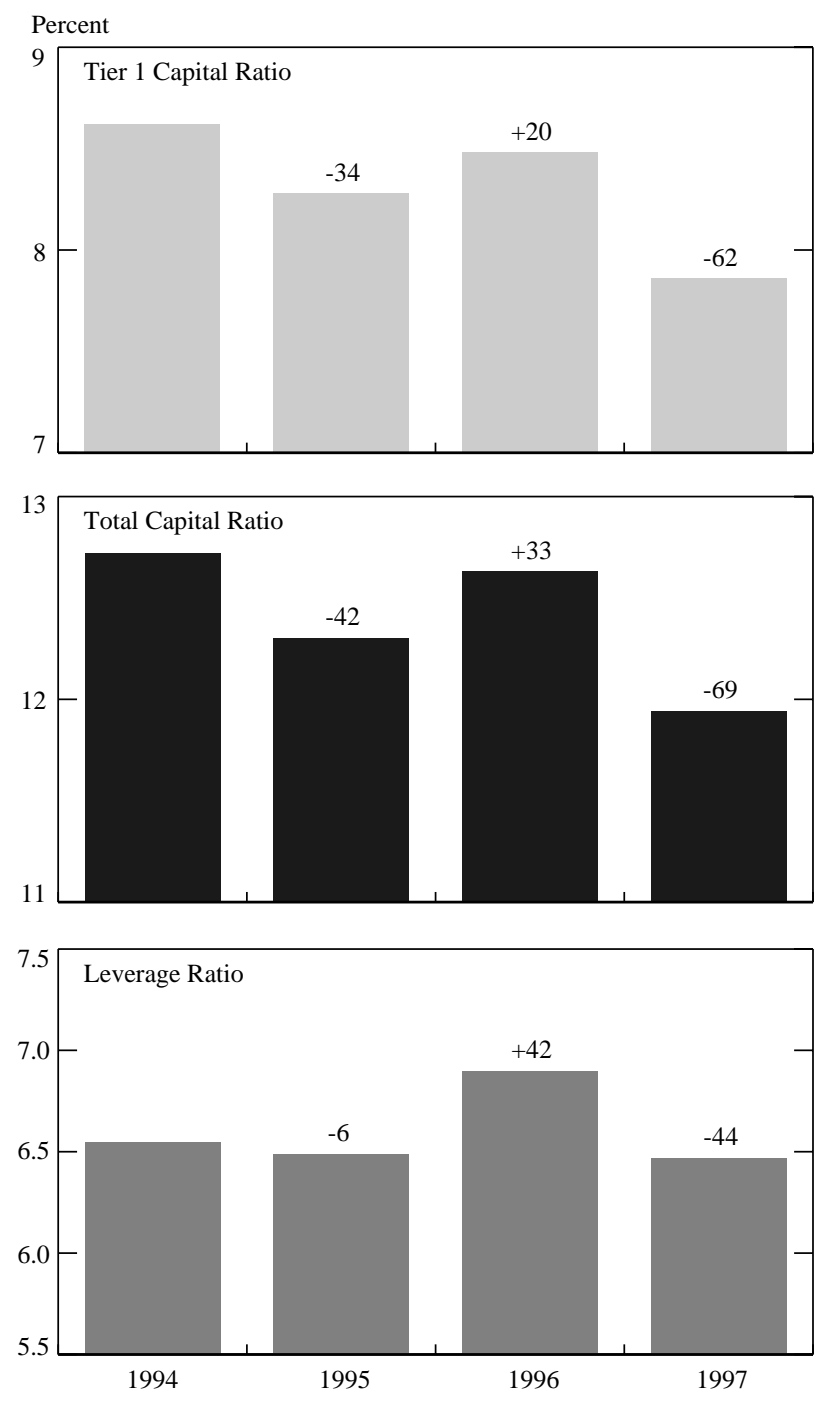

Notes: Ratios are for the twenty-five largest U.S. bank holding companies at the end of 1997 (with assets of $\$ 45$ billion or more at that time). The tier 1 and total capital ratios are calculated as the ratios of tier 1 and total capital to an institution's risk-weighted assets; the leverage ratio is calculated as tier 1 capital divided by average total assets. The figures above the bars indicate the basis point changes in the ratios from the previous year. Data are as of year-end and have been adjusted to control for mergers.

capital bases is only one possible interpretation. We might also see the drop as a strategic move by banks to manage their capital positions in the wake of several years of high profitability and the resultant buildup in capital.

To determine which interpretation best fits the evidence, we examine the relationship between the size of the decline in the risk-based capital ratios and the initial 
level of those ratios for the twenty-five largest U.S. bank holding companies. Chart 2 presents a scatterplot of the year-end 1996 total capital ratio against the 1997 change in the ratio; the downward-sloping line in the chart is the estimated regression line between the two variables. As the regression line indicates, there is a negative relationship between the initial level of the total capital ratio and the subsequent drop in the ratio, suggesting that bank holding companies with higher capital ratios at the end of 1996 tended to have larger declines in those ratios during 1997. ${ }^{4}$ While there is significant variation among the twenty-five bank holding companies in the sample, the overall relationship is consistent with the idea that these institutions were attempting to move their capital ratios toward some relatively similar target level. That is, we would expect to see a negative relationship between capital ratio levels and subsequent changes if banking companies were actively managing their capital ratios around a target level determined by market forces or by their desire not to deviate from a peer group standard.

\section{Composition of Bank Holding Companies' 1997 Changes in Capital Positions}

Bank holding companies appear to be actively managing their capital ratios. How, then, are they accomplishing this objective? We can develop some insight into this issue through a closer examination of the mechanics

\section{Chart 2 \\ 1997 Change in Large Bank Holding Companies' Total Capital Ratio}

1997 change in ratio

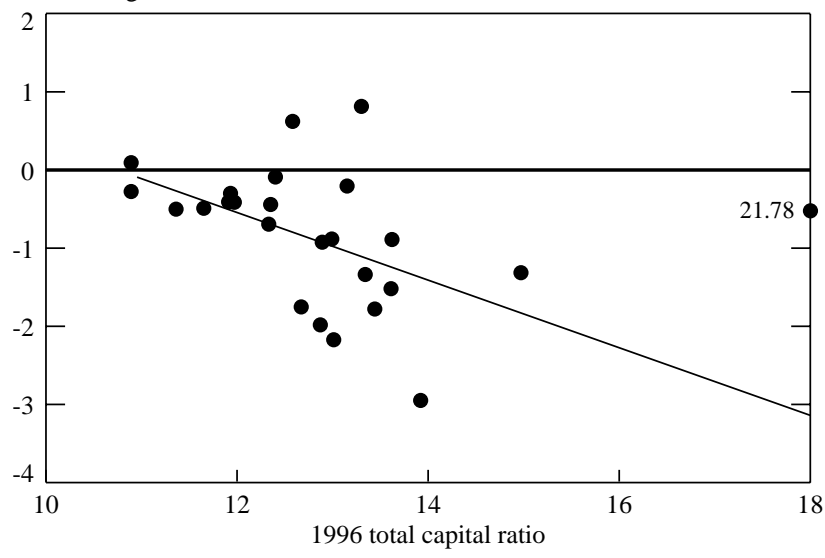

Notes: The chart plots the relationship between the year-end 1996 total capital ratio and the 1997 change in the ratio. It suggests that bank holding companies with higher capital ratios at the end of 1996 had sharper declines in those ratios in 1997. Data are for the twenty-five largest U.S. bank holding companies at the end of 1997 (with assets of \$45 billion or more at that time). Year-end capital ratios for 1996 have been adjusted to control for mergers.
Growth from Prior Year in Large Bank Holding Companies' Capital, Risk-Weighted Assets, and Total Assets

Percentage Change

\begin{tabular}{ccccc} 
Year & $\begin{array}{c}\text { Tier } 1 \\
\text { Capital }\end{array}$ & $\begin{array}{c}\text { Total } \\
\text { Capital }\end{array}$ & $\begin{array}{c}\text { Risk-Weighted } \\
\text { Assets }\end{array}$ & $\begin{array}{c}\text { Average } \\
\text { Total Assets }\end{array}$ \\
\hline 1997 & 1.56 & 3.58 & 9.55 & 8.41 \\
1996 & 9.83 & 10.13 & 7.27 & 3.22 \\
1995 & 5.92 & 6.56 & 10.22 & 6.95 \\
1994 & 5.94 & 5.44 & 7.54 & 8.81 \\
\hline
\end{tabular}

Source: Board of Governors of the Federal Reserve System, "Consolidated Financial Statements for Bank Holding Companies-FR Y-9C."

Notes: Data are for the twenty-five largest U.S. bank holding companies (with assets of $\$ 45$ billion or more). Data have been adjusted to control for mergers.

behind the decrease in regulatory capital ratios for the twenty-five largest U.S. bank holding companies (see table). The first thing to note is that the drop in capital ratios during 1997 was not fueled by an outright fall in the tier 1 and total capital holdings of these institutions. Both regulatory capital measures increased slightly, though at considerably slower rates than in the three preceding years. These slower than average growth rates contrast sharply with the growth rates of risk-weighted assets and average total assets, both of which rose at rates more in line with those in 1994-96 (though near the high end of this range). Taken together, these figures suggest that the decline in regulatory capital ratios in 1997 reflected an unusual slowdown in the growth of capital holdings more than an unusual increase in total or risk-weighted assets.

Further insight into the issue of capital management is provided by Chart 3, which breaks down the change in bank holding companies' equity capital positions into its various components. Note that equity capital does not precisely correspond to the definition of tier 1 capital used for regulatory capital purposes, though there is considerable overlap between the two concepts. ${ }^{5}$ We examine equity capital here because detailed information about the sources of change in equity capital is provided in bank holding companies' regulatory reports.

The chart divides the overall change in equity capital from year-end 1996 to year-end 1997 into two broad components. The first is contributions from operating activities (net income and unrealized gains on available-for-sale securities), reflecting basic profitability; the second is shareholder payouts (net issuance of common and preferred stock, net change in treasury stock, and dividend payments), which reflect ways that earnings can be transferred to shareholders. 


\section{Chart 3 \\ Components of the 1997 Change in Large Bank Holding Companies' Equity Capital Positions}

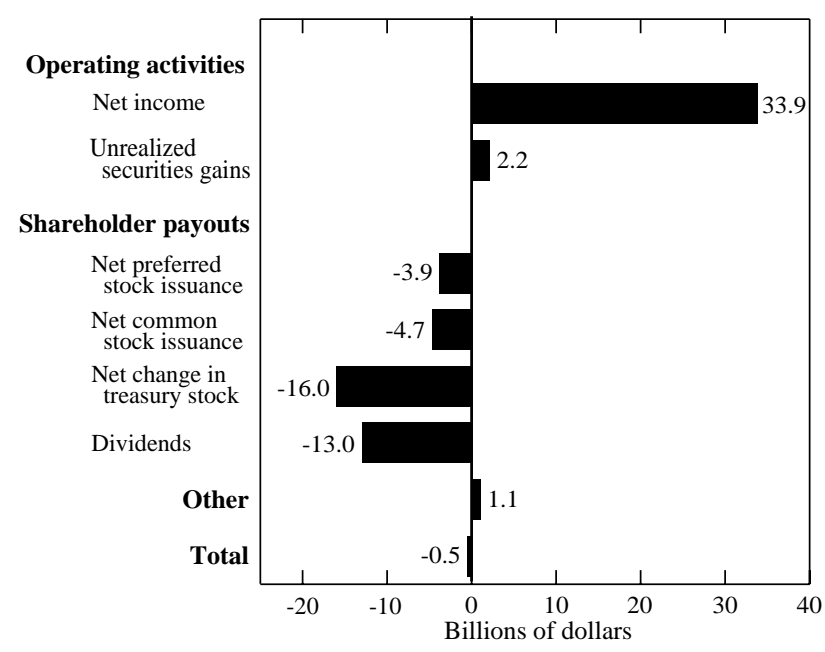

Source: Board of Governors of the Federal Reserve System, "Consolidated Financial Statements for Bank Holding Companies-FR Y-9C."

Notes: Data are for the twenty-five largest U.S. bank holding companies at the end of 1997 (with assets of $\$ 45$ billion or more at that time). Year-end equity capital levels for 1996 have been adjusted to control for mergers.

Since shareholder payouts are the focus of our analysis, we consider in more detail how these transactions allow institutions to pass on their earnings. Dividend payments are direct cash distributions of earnings to shareholders. Net issuance of common and preferred stock is the difference between new stock issued and stock retired; this difference reflects the net change in the total volume of a bank holding company's common and preferred stock. The total volume of stock, in turn, can be divided into two segments: the portion held by shareholders (issued and outstanding stock) and the portion repurchased from shareholders by the bank holding company (treasury stock). Repurchased stock may be held by the bank as treasury stock or retired. Bank holding companies often repurchase stock in order to distribute earnings to shareholders without altering dividends or exposing shareholders to the taxes due on dividend payments. Net issuance of common and preferred stock plus the net change in treasury stock represents the total net amount of earnings returned to shareholders through stock repurchases.

In 1997, a sizable portion of bank holding company earnings was paid to shareholders as dividends and stock repurchases (Chart 3). Significantly, although the dollar value of the twenty-five largest bank holding companies' dividend payments increased about 5 percent from 1996 levels, the dollar value of the companies' stock repur- chases surged-rising by nearly 70 percent. As a result, aggregate shareholder payouts by these institutions exceeded net income by more than 10 percent in 1997. This was the first time that these institutions paid out more than they earned during the highly profitable period beginning in the mid-1990s. While the pattern for individual institutions varied, fifteen of the twenty-five largest made shareholder payouts that exceeded net income during 1997.

The dramatic growth in shareholder payout rates in 1997 continued a trend of increasing rates going back to the early 1990s (Chart 4, solid line). Much of this growth was fueled by the twenty-five largest bank holding companies' increased reliance on stock repurchases to return earnings to shareholders (Chart 4, dotted line). Net stock repurchases were positive and growing after 1993, indicating that the repurchases were acting to reduce the amount of equity capital outstanding for these companies (all else equal). In contrast, the average dividend payout ratio held fairly constant over this period (Chart 4, dashed line). The combined result of these two trends is that stock repurchases exceeded dividend payments during 1997.

\section{Is There Reason for Concern?}

The fact that aggregate shareholder payouts represent such a large portion of bank holding companies' net income could give rise to concerns about banking institutions' future capital positions. Specifically, if bank

\section{Chart 4 \\ Large Bank Holding Companies' Total Shareholder Payouts, Dividends, and Net Stock Repurchases as a Percentage of Net Income}

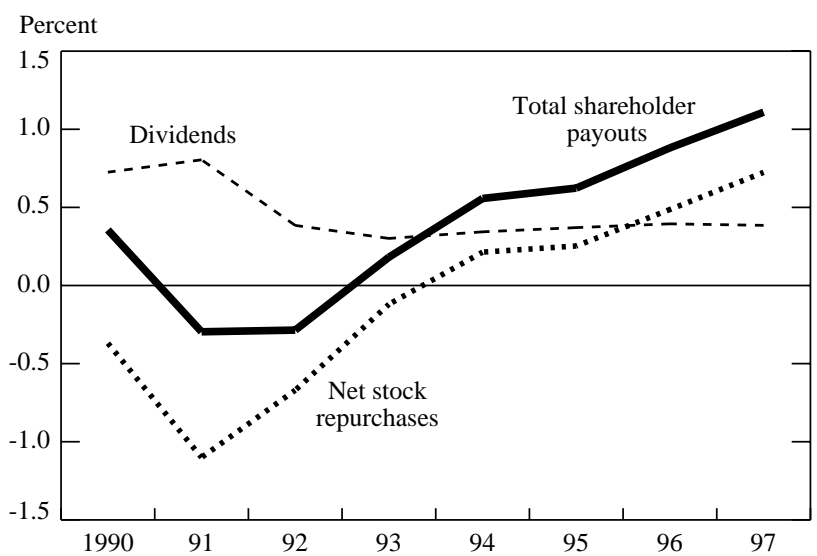

Source: Board of Governors of the Federal Reserve System, "Consolidated Financial Statements for Bank Holding Companies-FR Y-9C."

Notes: Data are for the twenty-five largest U.S. bank holding companies in each year. Total shareholder payouts equal dividends plus net stock repurchases. No adjustments have been made to control for mergers. 
holding companies were locked in to a high dollar level of payouts, then a future decline in earnings could drain capital resources. Such a drain could occur if these institutions were unable or unwilling to respond quickly to a decline in earnings, so that the reduction in payouts followed the earnings decline only with a lag.

To assess the importance of this concern, we need to place these developments in their proper context. U.S. banking companies have experienced several consecutive years of strong earnings and healthy capital ratios. In this environment, if banking companies felt that they had acquired sufficient capital to withstand potential future losses during an industry down-cycle, they would then face the issue of how to manage any additional accumulating capital resources. One possibility would be for them to seek out new investment opportunities and increase the scale or riskiness of their activities. In capital ratio terms, banking companies adopting this strategy would increase their riskweighted assets, which, as the table indicates, the companies have done to some degree. However, identifying good investment opportunities could become increasingly difficult in a market in which many banks were following this strategy, and as a result, banks might have to take on riskier exposures to obtain an adequate return on capital.

Our evidence suggests that bank holding companies have, to a large extent, opted to pursue a different strategy. Specifically, the increased rate of stock repurchases and the steady rate of dividend payments are consistent with the argument that banking companies are instead returning earnings to shareholders. ${ }^{6}$ In theory, this strategy is economically efficient, since shareholders should prefer this approach to the alternative of having a bank take on excessively risky exposures. ${ }^{7}$

What, then, are the implications of the payout strategy if future bank earnings declined significantly? The role of stock repurchases in the recent growth of shareholder payout rates is an important factor in answering this question. As noted earlier, nearly all of this growth can be attributed to the impact of stock repurchases. Compared with dividend payments, stock repurchases generally provide bank holding companies with more flexibility to adjust shareholder payments over time in response to fluctuations in earnings. Bank holding companies (and other firms) tend to change dividend rates only infrequently, because such changes are often seen by investors as an indication of the private information that companies have about their future earning prospects. Thus, banking companies may be reluctant to reduce dividends in the face of a drop in earnings, either because they are unsure if the drop is just a temporary phenomenon or because they are concerned about sending a negative signal to the markets about their long-run profitability.
In contrast, banking companies have considerably more leeway to alter stock repurchases in response to fluctuations in profitability-in large part because the markets are much less sensitive to such actions. As Chart 4 makes clear, stock repurchases exhibited significantly more movement over the 1990s banking industry cycle than did dividend payments. This cyclical response to the rise and fall of profits was reinforced by Federal Reserve System regulations requiring bank holding companies to receive supervisory approval before making large stock repurchases. Because stock repurchases affect regulatory capital, the Federal Reserve prohibits companies from making repurchases that would threaten their ability to meet capital adequacy standards.

The greater responsiveness of stock repurchases to changes in earnings suggests that the current high rate of shareholder payouts is not a strong signal of future capital constraints on banking institutions. If bank earnings were to drop significantly_perhaps because of a credit cycle downturn or losses in a particular lending sector-banks' flexibility to alter stock repurchases would provide a considerable cushion before equity holdings were affected. Specifically, because stock repurchases represented considerably more than half of their net income in 1997 (Chart 4), banking companies could eliminate these transactions and not experience a decline in equity capital until earnings fell by more than 70 percent. This calculation assumes that all other elements in the capital accumulation process remain constant, which might not be true in a real cyclical downturn. Nonetheless, the calculation suggests that banks' high shareholder payout rates are not a cause for immediate concern.

\section{Conclusion}

The noticeable decline in capital ratios of U.S. bank holding companies in 1997 could cast doubt on these institutions' future capital strength. Our analysis, however, indicates that concerns of this type may be premature. We find that the drop in ratios is attributable largely to bank holding companies' efforts to manage their capital positions by returning earnings to shareholders, rather than to an unusually large rise in riskweighted exposures. Following a period of strong, sustained profitability, the twenty-five largest U.S. bank holding companies sharply increased their payouts to shareholders in 1997, in the form of dividend payments and stock repurchases. Significantly, most of this increase resulted from a surge in stock repurchases, which provide banking companies with greater short-term flexibility than dividends do. Should the companies' future income deteriorate, the repurchases would provide a large cushion before equity holdings were affected. 


\section{Notes}

1. See Board of Governors of the Federal Reserve System (1997, pp. 33-65, 77-8) for full definitions of tier 1 and total capital, as well as descriptions of the various regulatory capital ratios.

2. As of June 1998, bank holding companies that have been assigned the highest supervisory rating or that have adopted the capital requirements for market risk exposures have a minimum leverage ratio requirement of 3 percent. All other bank holding companies have a requirement of 4 percent. See Board of Governors of the Federal Reserve System (1998) for more details.

3. Except where noted, pre-1997 data for the twenty-five largest banking companies have been adjusted to control for the impact of bank mergers. Because of data limitations, nonbank mergers (such as acquisitions of nonbank subsidiaries other than those acquired through bank holding company mergers) have not been included in the adjustments. The results of the analysis are not significantly affected by these adjustments.

Comparisons of 1996 and 1997 risk-based capital ratios may be affected by the impact of the capital requirements for market risk, which banks and bank holding companies had the option of adopting during 1997. Three very large bank holding companies chose to do so. While it is difficult to estimate precisely the impact of the market risk requirements on the tier 1 and total capital ratios, approximations indicate that the impact may be fairly small (see Hendricks and Hirtle [1997]). In any case, the ratios for these three institutions do not appear to be driving the overall results.

4. Similar relationships exist for the tier 1 capital ratio and the leverage ratio. The regression results indicate that these relationships are statistically significant for the total capital and tier 1 capital ratios, though not for the leverage ratio. These regressions omit one outlier observation for which the total and tier 1 capital ratios far exceed the corresponding ratios for the remaining twenty-four bank holding companies. If the outlier is included in the regression, the negative relationship remains, but it is not statistically significant.
5. Equity capital includes some preferred stock instruments and other elements (such as unrealized gains on available-for-sale securities) excluded from tier 1 capital, while tier 1 capital includes some elements (such as minority interests in consolidated subsidiaries) not included in equity capital. Overall, however, the basic elements of the two capital concepts-common stock plus surplus-are the same.

6. Of course, it is possible that these companies increased their risk profiles in ways that did not raise risk-weighted assets. For instance, they could have increased the riskiness of their assets within a risk category or taken on positions that do not accrue a regulatory capital charge commensurate with their actual risk exposures. Our data do not allow us to identify such increases in risk exposure. Thus it is entirely possible that bank holding companies both increased payouts to shareholders and took on riskier exposures during 1997. If so, the decline in regulatory capital ratios could prove considerably more troublesome.

7. See Jensen (1986) for a discussion of the incentives that might lead firm managers to misinvest "free cash flow."

\section{References}

Board of Governors of the Federal Reserve System. 1997. Capital Adequacy Guidelines.

1998. "Leverage Capital Standards: Tier 1 Leverage Ratio." Federal Register 63, no.107: 30369-70.

Hendricks, Darryll, and Beverly Hirtle. 1997. "Bank Capital Requirements for Market Risk: The Internal Models Approach." Federal Reserve Bank of New York Economic Policy Review 3, no. 4: 1-12.

Jensen, Michael C. 1986. "Agency Costs of Free Cash Flow, Corporate Finance, and Takeovers." American Economic Review 76, no. 2: 323-9.

\section{About the Author}

Beverly Hirtle is a vice president in the Banking Studies Function of the Research and Market Analysis Group.

The views expressed in this article are those of the author and do not necessarily reflect the position of the Federal Reserve Bank of New York or the Federal Reserve System.

Current Issues in Economics and Finance is published by the Research and Market Analysis Group of the Federal Reserve Bank of New York. Dorothy Meadow Sobol is the editor.

Editorial Staff: Valerie LaPorte, Mike De Mott, Elizabeth Miranda

Production: Carol Perlmutter, Lingya Dubinsky, Jane Urry

Subscriptions to Current Issues are free. Write to the Public Information Department, Federal Reserve Bank of New York, 33 Liberty Street, New York, N.Y. 10045-0001, or call 212-720-6134. Current Issues is also available at the Research and Market Analysis Group's web site: http://www.ny.frb.org/rmaghome/curr_iss/1998.htm. 